\title{
Banchoff, T. i Casanova, J. (red.). (2016), The Jesuits and Glo- balization: Historical Legacies and Contemporary Challenges. Georgetown University Press (Washington, D.C., ss. 299)
}

Recenzowana książka to owoc rocznych badań grupy znakomitych uczonych, skupionych przez redaktorów Thomasa Banchoffa i José Casanovę. Projekt był realizowany przez Berkley Center of Religion, Peace and World Affairs na Georgetown University w Waszyngtonie. Główne pytania postawione przed zespołem brzmiały: co doświadczenie globalizacji mówi nam o Towarzystwie Jezusowym (jezuitach)? A co doświadczenie jezuitów mówi nam o globalizacji? Jak zapisano w tytule, tekst podzielony jest na dwie zasadnicze części: dziedzictwo historyczne i wyzwania współczesne. Kwestie te nadają treść ogólnemu schematowi pojęciowemu publikacji, historycznie podzielonego na trzy wielkie „fale globalizacji”.

Pierwsze wieki istnienia Towarzystwa Jezusowego, aż do jego kasaty w 1773 r. przez papieża Klemensa XIV, odpowiadają pierwszej wczesnej globalizacji. W tym okresie zakon wykorzystuje możliwości ekspansji jak żadna inna instytucja - świecka czy religijna - $i$ to nie tylko $w$ sensie geograficznym. Inaczej mówiąc, ta globalizacja materializuje się przede wszystkim w szkołach i misjach.

Druga fala, nazywana nowoczesną fazą globalizacji, naznaczona jest m.in. masowymi migracjami do Stanów Zjednoczonych oraz procesami kolonizacji na różnych kontynentach, zwłaszcza w Afryce. Ta faza w historii jezuitów odpowiada okresowi od przywrócenia zakonu w 1814 roku aż do połowy XX wieku - do Soboru Watykańskiego II. W tej fazie jezuici utracili wiele ze swojej poprzedniej dynamiki misyjnej na płaszczyźnie międzykulturowej, a tym samym globalne znaczenie.

$\mathrm{Na}$ koniec analizowana jest kwestia globalizacji epoki współczesnej. Wśród wielu cech tej fazy wskazuje się przede wszystkim na Powszechną deklarację praw człowieka, która wysuwa na pierwszy plan świadomość przynależności do wspólnoty międzyludzkiej, co w pewnej mierze reprezentuje subiektywny wymiar globalizacji. Elementy te zostały wzmocnione wraz z końcem zimnej wojny, upadkiem muru berlińskiego, a także z ogromnym impulsem rewolucji technologicznej i komunikacyjnej. W ten sposób skonfigurowany został świat, który słusznie można uznać za "globalną wioskę".

$Z$ eklezjalnego i jezuickiego punktu widzenia ten etap globalizacji rozpoczyna się wraz z Soborem Watykańskim II i większym otwarciem Kościoła katolickiego na pluralistyczny kulturowo świat. W perspektywie zakonu jest to związane z pełnieniem funkcji przełożonego generalnego przez charyzmatycznego ojca Pedro Arrupe SJ. Czas jego rządów to prawie dwadzieścia lat (1965-1983), które charakteryzują się globalnym impulsem misyjnym. Jak stwierdza Casanova, była to dla zakonu „nowa globalna transformacja". Pomimo znacznego zmniejszenia liczebności zakonu stał się on na nowo "globalną siecią". 


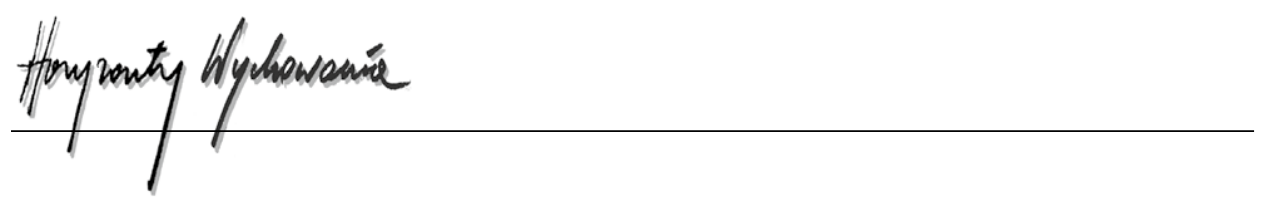

Powyższe kwestie analizowane są w trzynastu rozdziałach książki podzielonych na dwie duże sekcje. Pierwsza część „Perspektywy historyczne” zawiera siedem analiz odnoszących się do jezuickich doświadczeń globalizacyjnych. Odpowiadają one dwóm pierwszym, wskazanym powyżej, etapom: „wczesnej globalizacji” i „nowoczesnej globalizacji”. Ta część zawiera rozważania znanych specjalistów od kwestii misyjnych w Azji (M. Anthony J. Ucerler SJ), a także opisuje spory z doktryną reinkarnacji (Francis X. Clooney SJ), jak również spory z islamem (Daniel A. Madigan SJ). Dodatkowo także podejmowane są kwestie związane z misją w Iberoameryce (Aliocha Maldavsky), historią antyjezuityzmu z perspektywy globalnej (Sabina Pavone), a także przywróceniem Towarzystwa Jezusowego w wymiarze globalnym (John T. McGreevy), jak również edukacją jezuicką i jej związku z globalizacją (John W. O'Malley SJ).

Druga część - „Współczesne wyzwania”, jak sugeruje tytuł, podejmuje kwestie związane ze współczesną globalizacją. Kolejne rozdziały, odpowiednio od 8 do 13 skupiają się na takich aspektach, jak „uniwersalne dobro” jako kluczowa koncepcja dzisiejszej misji jezuickiej (David Hollenbach SJ), zaangażowanie zakonu na rzecz sprawiedliwości społecznej w Ameryce Łacińskiej (Maria Clara Lucchetti Bingemer). Ponadto mowa jest o pracy zakonu dla rozwoju praw człowieka w Azji (John Joseph Puthenkalam SJ i Drew Rau), a także przedstawiono propozycje zakonu w kwestii opieki nad uchodźcami (Peter Ballais SJ), jak również jego zaangażowanie w szkolnictwo wyższe (Thomas Banchoff). Rozdział 13 i ostatni to interesująca synteza autorstwa Casanovy, zatytułowana: Jezuici przez pryzmat globalizacji, globalizacja przez pryzmat jezuitów.

Recenzowaną książkę można uznać za znaczący wkład w hermeneutykę historyczną. Prezentuje ona interpretację historii nie jako zwykły ciąg wydarzeń, dokładnie udokumentowanych, ale interpretuje ją na podstawie kontekstu społeczno-kulturowego, w którym te wydarzenia mają miejsce. Praca w sposób twórczy odpowiada na pytania stawiane na wstępie. Przedstawione analizy są wystarczającym uzasadnieniem, aby można było stwierdzić na ich podstawie, że jezuici byli jedną z pierwszych zorganizowanych grup w historii, która myślała i działała globalnie, na długo zanim istniały obecnie obowiązujące globalne warunki zdolne do podtrzymania takich praktyk. Aby to osiągnąć, wykorzystali w dużym stopniu dostępne im „zewnętrzne” możliwości, m.in. fenomen iberyjskiej ekspansji kolonialnej w Nowych Indiach czy humanizm chrześcijańskiego renesansu realizowany w szkołach. Te i inne możliwości były dostępne dla wszystkich, jednak, jak argumentują autorzy omawianej pracy, to jezuici potrafili je wykorzystać w sposób bardziej twórczy niż pozostali.

Ponadto, zdaniem autorów, źródłem globalnego sukcesu Towarzystwa Jezusowego jest także potencjał tkwiący w jego duchowości. To właśnie ona w swoim najbardziej autentycznym wyrazie, czyli Ćwiczeniach duchowych, promuje wizję uniwersalną, która wzywa do unikania stale obecnego niebezpieczeństwa eurocentryzmu. Równocześnie hierarchiczna i scentralizowana organizacja zakonu, wraz ze zdolnością dostosowywania się do zmieniających się okoliczności kontekstu „według miejsc, czasów i ludzi”, zapewniły jezuitom dużą elastyczność w trakcie realizacji misji. 
Recenzje

2021, Vol. 20, No. 56

Książka kończy się serią inspirujących pytań, które stanowią cenne uzupełnienie prezentowanych analiz, ale wskazują także na to, że omawiany proces ciągle trwa i jego kolejne etapy są kwestią otwartą.

Jarosław Charchuła

Akademia Ignatianum w Krakowie

DOI: 10.35765/hw.2200 